\title{
Mental budgeting and the malleability of decision-making
}

\author{
Honey Wahyuni Sugiharto Elgeka, ${ }^{1 *}$ Jianhong $\mathrm{Ma}^{2}$ \\ ${ }^{1}$ Faculty of Psychology, Universitas Surabaya, Surabaya - Indonesia; ${ }^{2}$ Department of Psychology and Behavioral \\ Sciences, Zhejiang University, Hangzhou - China
}

\begin{abstract}
Financial difficulties commonly occur in college students' lives. Problems might be caused by a lack of understanding about managing money, such as falling into the temptation of buying unnecessary discounted goods or choice justification. The research aims to understand how mental budgeting influences purchasing discounted items and choice justification. In the study, two experiments were undertaken to explain the reaction of discount, and two others to describe choice justification ( $\mathrm{N}=169$ in Indonesia, $\mathrm{N}=168$ in China). Mann-Whitney U and ANOVA tests were used to analyze the experiments. Mental budgeting scales were also employed in experiments 3 and 4. The results show that when individuals receive a discounted offer for luxury goods, they will fall into the temptation of buying them. This takes place because they do not want to lose the opportunity to obtain such goods at a cheap price. In addition, when individuals receive offers related to physiological needs (i.e., food), they will practice choice justification. This means that all people need to understand the concept of mental budgeting and make realistic budgets.
\end{abstract}

Keywords: discounting; choice justification; mental budgeting

\begin{abstract}
Abstrak: Kesulitan keuangan seringkali terjadi pada kehidupan mahasiswa. Masalah ini mungkin dapat terjadi karena kurangnya pengetahuan dalam mengelola uang, contohnya: tergoda untuk membeli barang diskon yang tidak diperlukan atau justifikasi pilihan. Penelitian ini bertujuan untuk memahami bagaimana penganggaran mental dapat memengaruhi individu dalam menghadapi diskon dan justifikasi pilihan. Pada penelitian ini dua eksperimen dilakukan untuk menjelaskan tentang diskon dan dua eksperimen lainnya untuk menjelaskan justifikasi pilihan ( $\mathrm{N}=169 \mathrm{di}$ Indonesia, $\mathrm{N}=168$ di Cina). Mann-Whitney $U$ dan ANOVA test dilakukan untuk menganalisis seluruh eksperimen. Selain itu, skala penganggaran mental juga digunakan pada eksperimen 3 dan 4 . Hasil penelitian ini menunjukkan ketika individu mendapatkan penawaran diskon pada barang mewah, umumnya mereka akan tergoda. Hal ini terjadi karena mereka tidak mau kehilangan kesempatan untuk mendapatkan barang mewah dengan harga murah. Selain itu, ketika individu mendapatkan penawaran terkait dengan kebutuhan fisiologis mereka akan melakukan justifikasi pilihan. Ini berarti setiap individu perlu memahami konsep penganggaran mental dan membuat anggaran yang realistis.
\end{abstract}

Kata Kunci: diskon; justifikasi pilihan; penganggaran mental

\footnotetext{
*Corresponding Author: Honey Wahyuni Sugiharto Elgeka (honeywahyuni@staff.ubaya.ac.id). Faculty of Psychology, Universitas Surabaya, Jl. Raya Kalirungkut, Surabaya 60293-Indonesia.
} 


\section{Introduction}

Every college student believes that they already manage their money well; however, some researchers have found that most experience financial difficulties (Daud et al., 2018; Huat et al., 2010; Jariah et al., 2004; Saidi et al., 2016; Susilowati et al., 2017). Financial problems for college students occur not only in Indonesia (Dwiastanti, 2015; Nidar \& Bestari, 2012; Pappang \& Anastasia, 2019) but also in China (Moon et al., 2014; Yao \& Meng, 2018). Researchers have found that college students have problems balancing income and expenses, as they love to buy things and spend money on having fun (Jariah et al., 2004). The impact of financial difficulties can be budget deficits or failure to repay credit or loans. This happens because students are unable to prioritize their needs, are incapable of planning their budgets, and fail to track their expenses (Daud et al., 2018; Jariah et al., 2004). This failure to manage money for spending or saving is due to the ignorance of mental budgets (Antonides et al., 2011).

Antonides et al. (2011) and Heath and Soll (1996) explain the concept of mental budgeting. It is a way for individuals to make a label on every account (such as transportation, accommodation, vacations, etc.), setting the budget for appropriate accounts, and tracking expenses. It means that individuals will be able to keep control of their spending and saving. Mental budgeting can help people to understand the cashflow of their money; when they are aware of such budgeting, they should be able to make good decisions in terms of spending and saving. In the concept of mental budgeting, when someone decides a budget, if they spend too much on one thing and less on another, they will easily discover this by tracking their expenses (Heath \& Soll, 1996).
It is known that individuals have the possibility to decide on a budget for their personal consumption, but it cannot be denied that their budget is determined by trial and error (Elgeka et al., 2018). The most important issue when making a budget is to be realistic; this allows individuals to pay more attention to saving and spending money in the future (Charupat \& Deaves, 2004; Elgeka et al., 2018). Heath and Soll (1996) state that the label of unidimensional resources (such as time and effort) evidently could be monitored well by splitting and labeling in the same way as other resources (such as money). This happens because individuals will monitor their self-control attempts and cognitive estimation. In fact, individuals will regret their consumption when they spend money on unnecessary items, especially when they use money already budgeted for other things (Levav \& Mcgraw, 2009).

However, the attractive offers that continually appear in college student life cannot be avoided, such as purchasing discounted item and choice justification (Cheema \& Soman, 2006; Cheng \& Cryder, 2018; Isabella et al., 2012; LaBarge \& Stinson, 2014; Lee \& Chen-Yu, 2018; Scheer et al., 2010). Indeed, mental budgeting sometimes influences reason-based choices, in which the reasons will justify the individual choices (Besharat, 2012). In the case of discounts, individuals will use the regular price as a reference and compare it with the actual price to make a decision (Bonini \& Rumiati, 2002). Zhou and $\mathrm{Gu}$ (2015) found that price reductions or discounts in monetary terms are more attractive than in percentage terms, which causes individuals to process the price information in an absolute or relative sense. That is the reason why retailers will use "sale" advertisements to attract people to buy products. Some will be snared by such price reductions and buy the product. This 
takes place when individuals abandon their mental budgets and make unplanned purchases.

Self-perception theory could explain discounting or price promotions, processes in which people are strongly influenced by purchase characteristics, especially by external causes (e.g., discounts), rather than internal ones (e.g., needing or liking goods) (Bem, 1972; Scott \& Yalch, 1978). Moreover, Scott and Yalch (1978) state that discounting can be considered as a reward and increases fun activity (purchasing). This theory suggests that individuals will face negative consequences of consumer behavior and attitude in the long term; it will influence their beliefs, affections, and attitudes (Mowen \& Voss, 2008).

On the other hand, prospect theory could also be used to explain the theory of promotions. Kahneman and Tversky (1984) state that individuals will discover the result of their choice in losses or gains. Other research has also found that people will use their perception of promotions or discounts in terms of loss or gain to decide to purchase the product and that sellers use this to create several types of promotion (Diamond \& Campbell, 1989; Kazmi, 2015; Scheer et al., 2010). Individuals will perceive gain if the purchase price (price promotion) is lower than the reference price; otherwise, when the purchase price is higher than the reference price, they will perceive loss (Crompton, 2016). However, with non-price promotion offers (percentage discount), people will segregate the purchase price (price promotion) from the reference price and perceive it as a gain. Moreover, when there is a price discount, people integrate the purchase price with promotional gain, viewing this as a way of reducing losses (Diamond \& Campbell, 1989). It can be concluded that non-price promotion will be perceived as gain and price promotion will be perceived as reduced losses.

The theory of mental budgeting states that individuals commonly make psychologically financial accounts in their brains and evaluate losses and gains from the cost and benefits they receive from some transactions (Diamond \& Campbell, 1989; Heath \& Soll, 1996; Shefrin \& Thaler, 1988). Scheer, Shehryar, and Wood (2010) found when people make tight budgets and receive price reductions in monetary units, a high price is mostly more acceptable than a cheap one. Other research by Gupta and Cooper (1992) found that if the discount is at a threshold level of $15 \%$ of the purchase price, individuals will still have the intention to buy the goods; nevertheless, the saturation level of discount is shown to be $40 \%$ of the purchase price, making people have low purchase intentions.

The next aspect discussed is called choice justification, which will be explained by the theory of want/should conflict (Bazerman et al., 1998). Some researchers have argued that individuals will make a decision not to choose 'want' (e.g., to eat pizza) but instead 'should' (e.g. healthy food) when the justification option is inadequate (Hsee, 1995, 1996; Kunda, 1990; Tetlock \& Kim, 1987). On the contrary, when an option is ambiguous for evaluation, individuals will construct justification and choose the desirable or attractive option (Cheema \& Soman, 2006). This happens when individuals selectively construe and control the option to justify the favored choice or judgment. In the theory of cognitive dissonance, Cooper and Fazio (1984) explain that after an individual makes a judgment, they will rationalize it. Moreover, choice or judgment is arranged by a sense of accountability 
(Tetlock \& Boettger, 1989; Tetlock \& Kim, 1987) and objectivity (Pyszczynski \& Greenberg, 1987). That is why an individual will not randomly choose 'want' even if the choice is desirable or attractive (Cheema \& Soman, 2006; Klein \& Kunda, 1992; Kunda, 1990).

The want/should conflict involves two types of factor: (a) judgments made by individuals based on 'should' deliberation, known as justifiable factors; and (b) judgments made using the 'want' option through deliberation, even though people know they should not do it, also referred to as unjustifiable factors (Hsee, 1996). In fact, the concept of the want/should conflict was discussed several years ago, for example by Thaler and Shefrin (1981), who refer to the planner and doer; by Loewenstein (1996), in terms of visceral influences; and by Freud (1959), in his concept of the id and superego. The want/should conflict also takes place when individuals face discriminatory bias or selfserving motivation. Concerning the want/should conflict theory, some research has found that want is conceived as "vice", connoted by negative payoffs, and focus on the here and now (e.g., risky sexual behavior, smoking, drinking, etc.). On the other hand, 'should' can be described as "virtues", reflected in positive payoffs and focus on the long term (Bazerman et al., 1998; Ly et al., 2013; Milkman et al., 2007, 2008, 2010; Nordgren et al., 2008; Okada, 2005; Polman et al., 2016; Read et al., 1999; Thaler \& Benartzi, 2004; Wertenbroch, 1998). Frequently, individuals will choose the want option when they face a conflict between want and should, and will use elasticity as a final decision on the want option (Hsee, 1996). This mostly takes place because the want option is more existentially attractive and affective than the should option (Okada, 2005).
Schweitzer and Hsee (2002) argue that the justification of choice occurs because of the selfdecision deceit, especially when individuals use normative or non-normative justification to deceive. Hence, the want/should conflict concept cannot be separated from the process of selfjustification. Fennema and Perkins (2008) found that justification is a physical and mental process to describe a decision. Individuals mostly undertake to build rational justification based on their knowledge and will make a desirable conclusion (Klein \& Kunda, 1992). Moreover, justification can also be built by the slope of biased memory and external information (Klein \& Kunda, 1992; Marin et al., 1987; Sanitioso et al., 1990). Erlandsson, Björklund, and Bäckström (2017), Krosch, Figner, and Weber (2012) and Weber and Lindemann (2008) argue that when individuals make a decision, this will be made with the head, with the heart, or by the book, which is the form of justification. Tetlock, Skitka, and Boettger (1989) argue that when an individual performs decision accountability (e.g., asking other people to confirm their decision), they will usually reach better decisions and reduce bias heuristics belief. This means individuals are more careful about their consideration, thinking in a multi-dimensional, complex, and flexible way (Malaviya \& Sivakumar, 2002).

Bazerman et al. (1998) and Bitterly, Mislavsky, Dai, and Milkman (2014) found that the consequences of the want/should conflict were affected by for how long the individual made an evaluation; the evaluation is made in a part or in unison. Even though the want option is mostly preferred to the should option, individuals tend to think about every option's cost and advantage, with the should option 
seeming more thoughtful when multiple options are evaluated simultaneously. In this study, mental budgeting can be adopted to devise a better strategy, and the quality of decisions can be improved, especially when people can justify their decision. Mental budgeting can be used to reduce the justification when an individual has already made a financial account before making a decision (Fennema \& Perkins, 2008).

Based on the overall situation that people face, especially in early adulthood, it would be fascinating to understand the decision-making preferences regarding discounting and choice justification. It is important to understand the role of mental budgeting when individuals make decisions. This research proposes two hypotheses:

Hypothesis 1: Mental budgeting will make individuals respectful of their budget when they receive discount offers.

Hypothesis 2: When individuals practice mental budgeting, they will not make the 'want' choice.

The research involves two situations that will be measured, the first related to discounts, and the second to choice justification. To this end, four experiments will be conducted. In the case of discounts (experiments 1 and 2), Tversky and Kahneman's (1981) study is replicated and modified, while in the case of choice justification (experiments 3 and 4), Cheema and Soman's (2006) study is modified.

\section{Experiment 1}

\section{Method}

In this experiment, the subjects were 100 students from the University of Surabaya (Indonesia); as one did not complete the task, ninety-nine (99) subjects were analyzed. The selection criteria were that participants were aged between 18 and 25 and were active college students. The experiment was conducted using a paper and pencil questionnaire. The average age of the subjects was 19.95 ( $\mathrm{SD}=0.89$ ); 50 were females and 49 males. For the experimental design, the case of the book and T-shirt problem modified from Tversky and Kahneman (1981) was used. The subjects were randomization in two case variants. In the first, the students were expected to buy low-price books and an exclusive t-shirt, whereas in the second they were expected to buy expensive books and a cheap t-shirt. All the budget expenses refer to the total price of books and t-shirts. In the experiment, the subjects were given several instructions; the price in parentheses relates to the first variant, while that in brackets relates to the second. The prices of the two purchases were Rp 30,000.00 and Rp. 150,000.00, and the book reduction was $33.3 \%$ off the regular or reference price. The experimental case was as follows:

"Imagine that you decide to purchase a book for (Rp 30.000,00) [Rp 150.000,00] and a T-Shirt for (Rp 150.000,00) [Rp. 30.000,00]. You leave your house with Rp. 180,000.00 in your pocket. At the store, the bookseller informs you that the book you wish to buy is on sale for (Rp. 20.000,00) [Rp. 100.000,00] at the other branch of the store, which is located 20 minutes' drive away. Would you make a trip to the other store?"

\section{Result and Discussion}

In the first variant, $40 \%$ (20 subjects) accepted the book discount, while in the second variant 91.8\% (45 subjects) accepted the discount. According to the Mann-Whitney $U$ test, the results show that $\mathrm{z}=-5.40, \mathrm{p}<.05$; the second variant $(M=37.04)$ has a lower score than the first variant $(\mathrm{M}=62.70)$. This finding was aligned with the 
prospect theory concept, that most individuals will accept the discount or price reduction at a high price (expensive) than at low price (cheap) (Scheer et al., 2010), even though the level of discount is only $33.3 \%$. The results on the acceptance or rejection of the book discount are shown in Table 1.

\section{Experiment 2}

\section{Method}

One hundred (100) subjects from Zhejiang University (China) took part in this experiment. The selection criteria were also that participants were aged between 18-25 years and were active college students. A paper and pencil questionnaire was used in this experiment. The subjects' characteristics were an average age of 20.91 ( $\mathrm{SD}=2.17$ ), with 55 students female and 45 males. The experimental design was similar to that in experiment 1 , the difference being the percentage book discount, which was $40 \%$ off the regular or reference price. The case was:

"Imagine that you decide to purchase a book for (Rp 30.000,00) [Rp 150.000,00] and a T-Shirt for
(Rp 150.000,00) [Rp. 30.000,00]. You leave your house with Rp. 180.000,00 in your pocket. At the store, the bookseller informs you that the book you wish to buy is on sale for (Rp. $12.000,00$ ) [Rp. 60.000,00] at the other branch of the store, which is located 20 minutes' drive away. Would you make a trip to the other store?"

\section{Result and Discussion}

The results were similar to those of experiment 1; only 56\% (28 subjects) accepted the first variant, while 92\% (46 subjects) accepted the second. In this situation, the lower book price attracted the attention of the subjects, although the higher price remained the priority. With the Mann-Whitney U test $(\mathrm{z}=-4.08, \mathrm{p}<.05)$ it was shown that the lower price (first variant) had a higher score ( $M=59.50)$ than the higher price (second variant) $(\mathrm{M}=41.50)$. This experiment result is contrary to those of previous research; Gupta and Cooper (1992) found that if individuals received discount levels of up to $40 \%$ they would tend towards the low purchase intention. Table 2 shows the two book variants (low-high price).

Table 1

Percentage of Acceptance or Rejection of Book Discount in the Two Variants

\begin{tabular}{lll}
\hline & \multicolumn{2}{c}{ Two book variants } \\
\cline { 2 - 3 } & Low price book (Rp. 30,000.00) & $\begin{array}{l}\text { Expensive book (Rp. } \\
150,000.00)\end{array}$ \\
\hline Yes (accept book discount) & $20(40 \%)$ & $45(91.8 \%)$ \\
No (reject book discount) & $30(60 \%)$ & $4(8.2 \%)$ \\
\hline Total & 50 & 49 \\
\hline
\end{tabular}

Table 2

Percentage of Acceptance and Rejection of Book Discount in the Two Variants (low-high price)

\begin{tabular}{lll}
\hline \multirow{2}{*}{ Acceptance and Rejection } & \multicolumn{2}{c}{ Two book variants } \\
\cline { 2 - 3 } & $\begin{array}{l}\text { Low price book } \\
\text { (Rp. 30,000.00) }\end{array}$ & $\begin{array}{l}\text { Expensive book } \\
\text { (Rp. 150,000.00) }\end{array}$ \\
\hline Yes (accept book discount) & $28(56 \%)$ & $46(92 \%)$ \\
No (reject book discount) & $22(44 \%)$ & $4(8 \%)$ \\
\hline Total & 50 & 50 \\
\hline
\end{tabular}




\section{Experiment 3}

\section{Method}

The third experiment subjects were 70 students from the University of Surabaya (Indonesia), with the specifications that they were aged between 18-25 years old and active college students. The experiment was again conducted through a paper and pencil questionnaire. The average age of the subjects was $19.83(\mathrm{SD}=0.80$ ), with 40 females and 30 males. Before conducting the experiment, each participant was requested to fill in the Mental Budgeting Scale of Antonides et al. (2011), which contains four items using a 5-point Likert scale (from $1=$ totally disagree to $5=$ totally agree) (Cronbach's $\alpha=.70$ ). The experiment group was also requested to write down their budget per month, while the control group did not receive this instruction. The experiment was focused on the justification of budgeting that affected spending. For the experimental design, the case was modified from Cheema and Soman's (2006) study. The subjects were randomly assigned to choose the type of expense (mother's birthday gift vs casual clothes for themselves and a gift voucher). Here, all the expense budgets were already initially mentioned, while the subjects needed to choose between the want/should option. The case was:
"Imagine that you saved money for your mother's birthday gift totaling Rp. 200.000,00, and wanted buy a beautiful sweater. But when you arrived in the clothing store, there was apparently a promotion for casual clothing, if you spent Rp. 200.000,00 you would get a voucher for Rp. 50.000,00 for the next purchase. What would you do?"

\section{Result and Discussion}

This experiment classified the scores of mental budgeting into three categories: high, medium, and low. The results show that in the experiment group 28 subjects (80\%) were willing to buy the mother's birthday gift, while in the control group 25 subjects (71.4\%) were willing to buy the gift. Using a two-way ANOVA test $F(1.70)=1.13, p>.05$ no differences were found between the experiment and control groups; $F(1.70)=1.37, p>.05$ means there were no differences between the expense type; and also no differences in interaction between the experiment-control groups and expense type, as shown by $F(1.70)=0.34, p>.05$. These results show that when individuals have prepared their budget well, they will not easily be swayed by interesting options and make a justification, which means the want conflict is thwarted (Fennema \& Perkins, 2008). The results are shown in Table 3.

Table 3

Mental Budgeting Categories and Choice Justification (Mother's Birthday Gift vs Casual Clothes)

\begin{tabular}{lllll}
\hline \multirow{2}{*}{$\begin{array}{l}\text { Category of mental } \\
\text { budgeting }\end{array}$} & \multicolumn{2}{l}{$\begin{array}{l}\text { Experiment Group (35 Students) } \\
\text { Expense Type }\end{array}$} & $\begin{array}{l}\text { Control Group (35 Students) } \\
\text { Expense Type }\end{array}$ \\
\cline { 2 - 5 } & $\begin{array}{l}\text { Mother's birthday } \\
\text { gift }\end{array}$ & Casual clothes & Mother's birthday gift & Casual clothes \\
\hline High & $2(5.7 \%)$ & $0(0 \%)$ & $3(8.6 \%)$ & $1(2.9 \%)$ \\
Medium & $24(68.6 \%)$ & $6(17.1 \%)$ & $21(60 \%)$ & $8(22.9 \%)$ \\
Low & $2(5.7 \%)$ & $1(2.9 \%)$ & $1(2.9 \%)$ & $1(2.9 \%)$ \\
Sub Total & $28(80.0 \%)$ & $7(20.0 \%)$ & $25(71.4 \%)$ & $10(28 \mathrm{~s} .6 \%)$ \\
\hline Total & 35 & & 35 \\
\hline
\end{tabular}




\section{Experiment 4}

\section{Method}

Sixty-eight (68) students at Zhejiang University (China) took part in this experiment; as before, the specification was between 18-25 years and active college student status. A paper and pencil questionnaire was used. The experiment requirements and the way for respondents to fill in the mental budgeting scale were the same as in experiment 3. The subjects' average age was 21.34 ( $\mathrm{SD}=1.82) ; 22$ students were male and 46 females. The mental budgeting scale and design of this experiment were similar to experiment 3 , a difference being the expense type (paying for food already ordered vs. pasta). The rational justification to make a plan was necessary for the experiment, especially when facing want/should conflict options. The case was:

"Imagine that you saved Rp. 300,000.00 for your birthday party to treat your friends at a pizza restaurant. Once you and your friends finished enjoying the dishes and were full, suddenly a waiter came and offered a new pasta menu. The waiter said that because your order was over Rp. 250,000.00 you were entitled to a discount offer for a new pasta menu. The new pasta menu should be Rp.
$100.000,00$, but you could get it for Rp.50,000.00. What would you do?"

\section{Result and Discussion}

In this experiment, the results of the experiment group showed that 30 subjects (88.2\%) agreed to buy the new pasta, while in the control group, 27 subjects (79.4\%) agreed to buy the new pasta (have a second meal). To measure the differences between the experiment and control groups, the result was $F(1.68)=1.93$, $p>.05$; for the expense type $F(1.68)=7.24, p<$ .05; and for the interception between the experiment-control group and expense type $F(1.68)=0.51, p>.05$. All the data were analyzed using a two-way ANOVA test. The results also showed that food, as a primary need, will make individuals easily fall into temptation and order a second meal. In this experiment, food will have an experiential impact and lead to individuals choosing the want option (Okada, 2005). It is why individuals make a stretchiness of the final decision to choose the opposite of the should option, i.e., they want the option (Hsee, 1996).

The details of the role of the mental budgeting category and expense type are shown in Table 4

Table 4

Mental Budgeting Categories and Choice Justification (Paying for Food already Ordered vs. Pasta)

\begin{tabular}{lllll}
\hline & \multicolumn{2}{l}{$\begin{array}{l}\text { Experiment Group (34 students) } \\
\begin{array}{l}\text { Category of } \\
\text { mental } \\
\text { budgeting }\end{array}\end{array}$} & $\begin{array}{l}\text { Control Group (34 students) } \\
\text { Expense Type }\end{array}$ & \multicolumn{2}{l}{$\begin{array}{l}\text { Food already } \\
\text { ordered }\end{array}$} & Pasta & Food already ordered & Pasta \\
\cline { 2 - 5 } & $0(0 \%)$ & $2(5.9 \%)$ & $0(0 \%)$ & $1(2.9 \%)$ \\
High & $4(11.8 \%)$ & $27(79.4 \%)$ & $3(8.8 \%)$ & $24(70.6 \%)$ \\
Medium & $0(0 \%)$ & $1(2.9 \%)$ & $4(11.8 \%)$ & $2(5.9 \%)$ \\
Low & $4(11.8 \%)$ & $30(88.2 \%)$ & $7(20.6 \%)$ & $27(79.4 \%)$ \\
Sub Total & 34 & & 34 & \\
\hline Total & & & & \\
\hline
\end{tabular}




\section{General Discussion}

Based on the four experiments above, the researcher obtained several results. The concept of mental budgeting shows that when an individual makes a budget, labeling the account and tracking expenses could better control the expenses (Antonides et al., 2011). It is common in a student's life to find several traps that lead to confusion when deciding, such as discounts and choice justification. They will most likely fall into temptation, allowing their money to drain away faster; and in the end, they will have to ask their parents to provide some extra money. This shows that they still do not have the responsibility to manage their money properly.

\section{First, the Concept of the Discounting Case}

When individuals realized the amount of money they had, they were frequently willing to buy the book at a higher price (expensive), no matter how big the discount was. Bonini and Rumiati (2002) mention that when individuals compare the reference price and the actual price, they are able to decide, especially when they are offered a discount. The role of mental budgeting is to lead and control spending if individuals become afraid and use their mental "savings" account from the plan (Cheng \& Cryder, 2018; Heath \& Soll, 1996; Shefrin \& Thaler, 1988; Soman \& Cheema, 2011; Sussman \& O'Brien, 2016; Thaler \& Shefrin, 1981).

In fact, mental budgeting also gives pleasure from transactions, when there are individual profits from the discounted price (Crompton, 2016; Diamond \& Campbell, 1989; Prelec \& Loewenstein, 1998; Thaler, 2008). The prospect theory describes the various pricing heuristics that lead to falling temptation, which can outwit perception and decisions. Individuals also calculate the discount using the gains and losses concept. Everyone is concerned with loss aversion (the extent of pain related to losing money) (Crompton, 2011, 2016). In this case, when using the concept of prospect theory, the book discount was drawn as a part of the gains and losses, so they did not let the opportunity to make gains slip, so they were willing to buy the book.

Regarding self-perception theory, this experiment shows the acceptance of discount as part of the external cause, i.e. the discount itself (Bem, 1972; Scott \& Yalch, 1978). Basically, the self-perception theory proposes that discounts will have a negative long-term effect on individual attitudes and behavior. They will cause the formation of habit or repetition in buying things because of the discount, not because of their function.

Scheer et al. (2010) found that when people undertake mental budgeting, they will prefer to accept a high price rather than a low one. This means individuals will calculate the number of gains to obtain higher "pleasure machines" as a form of satisfaction. The interesting findings in this experiment were contrary to Gupta and Cooper (1992) results, who found that people have a low intention to buy when the level of discount is $40 \%$ of the purchase price. Nevertheless, different results were obtained in experiment 2; the extent of the discount was $40 \%$, but the number of subjects willing to buy the book was still high $(92 \%)$. This occurred because in this experiment the discount was mentioned in monetary terms, not percentage terms; Zhou and Gu (2015) state that monetary terms are more attractive than percentage terms, as they have a more absolute value (easier to calculate the gains). 
In the discount case, the hypothesis was not proven; in experiments 1 and 2 all the subjects chose to pay the high book price. This shows that when people have mental budgets, they will compute the goods' gains and losses. They will avoid loss aversion, the pain after losing money. It certainly will not be easy for them, but it will lead them to accept the discount.

\section{Second, the Choice Justification Case}

The different results obtained in experiments 3 and 4 will make every individual understand the priority in the want/should conflict. Cheema and Soman (2006) research found that ambiguous choice will tempt individuals, who will mostly go for the desired choice as the pleasing and agreeable option, even though they have already made mental budgets.

In fact, every individual has the responsibility for perseverance in their sense of accountability and objectivity (Pyszczynski \& Greenberg, 1987; Tetlock et al., 1989; Tetlock \& Kim, 1987); also to be brave in making a decision and not falling on the justification of the wrong decision (Cheema \& Soman, 2006; Klein \& Kunda, 1992; Kunda, 1990). Looking at the results of experiment 3 , most subjects were not tempted to buy casual clothes (by voucher) rather than the gift for their mother. This experiment's choice preferences do not seem attractive enough to bend people's judgment to buy other options. However, experiment 4 showed an interesting result; the type of food made the subjects choose the want option, with food apparently being a more attractive option than clothes.

According to Maslow (1943), in his renowned theory of the hierarchy of needs, food is a basic need of every human being. In experiment 4 , the subjects chose the new pasta as a way of meeting their basic needs. Although the subjects had already ordered pizza, in their curiosity to satisfy other physiological needs they willing to buy the new pasta (buy a second meal). Taormina and Gao (2013) state that if physiological needs are fulfilled in line with individuals' expectations, they will be satisfied and they will be related to emotion. Moreover, the decision to choose food was a "heart" option, the feeling that needs to be satisfied to individual expectation (Erlandsson et al., 2017; Krosch et al., 2012; Weber \& Lindemann, 2008).

As discussed in the category of mental budgeting in experiments 3 and 4, it makes sense if individual's decisions are still not stable; in their age so many ideas still came up to mind and may make them make the wrong decision. In early adulthood, people focus on the here and now, i.e., the want option (Bazerman et al., 1998; Ly et al., 2013; Milkman et al., 2007, 2008; Nordgren et al., 2008; Okada, 2005; Polman et al., 2016; Read et al., 1999; Thaler \& Benartzi, 2004; Wertenbroch, 1998). This appears in the case of the casual clothes expense type, which will not give instantaneous gratification, whereas new pasta will; immediate gratification is more attractive than the opposite (Baumeister et al., 1998; Bazerman et al., 1998; Polman et al., 2017). Even though individuals have already made a financial account and a budget, in fact, mental budgeting cannot always eliminate the choice justification, as Fennema and Perkins (2008) showed in their research. Therefore, hypothesis 2 was also not accepted; mental budgeting will continue to exist when the choices are not related to basic needs.

This research has limitations; for example, in experiments 1 and 2 the subjects did not receive mental budgeting scales to measure their condition. Without the results of this scale, the 
condition of the subjects could not be assessed clearly, although the results are still good enough for analysis. However, information about the mental budgeting scores will make the results complete.

The second limitation is that the subjects in the experiments were from Indonesia and China; nevertheless, the research does not consider the differences between the two cultures. The research focuses only on malleable decisionmaking towards mental budgeting, especially as these two countries face a similar situation, with financial problems in college students' lives. It would be important to understand the differences between the two countries through their cultures in future research.

\section{Conclusion}

When early adulthood life is observed, frequently young people face offers of discounts and several choices that force them make a justification. The understanding of how to use money by college students needs to be taught, especially in terms of maintaining their budget using the concept of mental budgeting. In fact, mental budgeting is unknown in young people's lives. Antonides et al. (2011) and Heath and Soll (1996) state that if individuals maintain their cashflow by tracking their expenses, they will overconsume in one account and under consume in other accounts.

Mental budgeting is a good way to examine people's expenses and savings; however, some young adults will say that they made their budget by trial and error. Elgeka et al. (2019) argue that mostly some budgets are made by trial and error, therefore it will have the possibility to fall on the temptation to buy unnecessary things. If people's budget is realistic, be expected discount and choice justification will not let them make the wrong decision. Charupat and Deaves (2004) and Elgeka et al. (2019) believe that realistic budgets will help individuals to care about their future savings and spending.[

\section{References}

Antonides, G., Manon de Groot, I., \& Fred van Raaij, W. (2011). Mental budgeting and the management of household finance. Journal of Economic Psychology, 32(4), 546-555. https://doi.org/10.1016/j.joep.2011.04.001

Baumeister, R. F., Bratslavsky, E., Muraven, M., \& Tice, D. M. (1998). Ego depletion: is the active self a limited resource? Journal of Personality and Social Psychology, 74(5), 1252-1265. https://doi.org/10.1037/0022-3514.74.5.1252

Bazerman, M. H., Tenbrunsel, A. E., \& Wade-Benzoni, K. (1998). Negotiating with yourself and losing: Making decisions with competing internal preferences. Academy of Management Review, 23(2), 225-241. https://doi.org/10.5465/AMR.1998.533224

Bem, D. J. (1972). Self-perception theory. Advances in Experimental Social Psychology, 6, 1-62. https://doi.org/10.1016/S0065-2601(08)60024-6

Besharat, A. (2012). Essays on mental accounting and consumers' decision making. University of South Florida.

Bitterly, T. B., Mislavsky, R., Dai, H., \& Milkman, K. L. (2014). Want/should conflict: A synthesis of past research. SSRN Electronic Journal, 244-264. https://doi.org/10.2139/ssrn.2403021 
Bonini, N., \& Rumiati, R. (2002). Acceptance of a price discount: The role of the semantic relatedness between purchases and the comparative price format. Journal of Behavioral Decision Making, 15(3), 203-220. https://doi.org/10.1002/bdm.411

Charupat, N., \& Deaves, R. (2004). How behavioral finance can assist financial planners. Journal of Personal Finance, 3(3), 41-52.

Cheema, A., \& Soman, D. (2006). Malleable mental accounting: The effect of flexibility on the justification of attractive spending and consumption decisions. Journal of Consumer Psychology, 16(1), 3344. https://doi.org/10.1207/s15327663jcp1601_6

Cheng, A., \& Cryder, C. (2018). Double mental discounting: When a single price promotion feels twice as nice. Journal of Marketing Research, 55(2), 226-238. https://doi.org/10.1509/jmr.15.0559

Cooper, J., \& Fazio, R. H. (1984). A new look at dissonance theory. Advance in Experimental Social Psychology, 17, 229-266. https://doi.org/10.1016/S0065-2601(08)60121-5

Crompton, J. L. (2011). A theoretical framework for formulating non-controversial prices for public park and recreation services. Journal of Leisure Research, 43(1), 1-29. https://doi.org/10.1080/00222216.2011.11950224

Crompton, J. L. (2016). Implications of prospect theory for the pricing of leisure services. Leisure Sciences, 38(4), 315-337. https://doi.org/10.1080/01490400.2015.1107516

Daud, N., Norwani, N. M., \& Yusof, R. (2018). Students financial problems in higher education institutions. International Journal of Academic Research in Business and Social Sciences, 8(10), 1558-1565. https://doi.org/10.6007/IJARBSS/v8-i10/5312

Diamond, W. D., \& Campbell, L. (1989). The framing of sales promotions: Effects on reference price change. Advances in Consumer Research, 16(1), 241-247.

Dwiastanti, A. (2015). Financial literacy as the foundation for individual financial behavior. Journal of Education and Practice, 6(33), 99-105.

Elgeka, H. W. S., Ma, J., Secapramana, L. V. H., \& Yudiarso, A. (2018). Money attitude and conscientiousness influence mental budgeting: A comparative study between Indonesia and China. Psychologia, 61(1), 26-36. https://doi.org/10.2117/psysoc.2019-A004

Erlandsson, A., Björklund, F., \& Bäckström, M. (2017). Choice-justifications after allocating resources in helping dilemmas. Judgment and Decision Making, 12(1), 60-80.

Fennema, M. G., \& Perkins, J. D. (2008). Mental budgeting versus marginal decision making: Training, experience and justification effects on decisions involving sunk costs. Journal of Behavioral Decision Making, 21(3), 225-239. https://doi.org/10.1002/bdm.585

Freud, S. (1959). Beyond the pleasure principle. W. W. Norton \& Company.

Gupta, S., \& Cooper, L. G. (1992). The discounting of discounts and promotion thresholds. Journal of Consumer Research, 19(3), 401-411. https://doi.org/10.1086/209310

Heath, C., \& Soll, J. B. (1996). Mental budgeting and consumer decisions. Journal of Consumer Research, 23(1), 40-52. https://doi.org/10.1086/209465

Hsee, C. K. (1995). Elastic justification: How tempting but task-irrelevant factors influence decisions. Organizational Behavior and Human Decision Processes, 62(3), 330-337.

Hsee, C. K. (1996). Elastic justification: How unjustifiable factors influence judgments. Organizational Behavior and Human Decision Processes, 66(1), 122-129. 
Huat, S. Y., Gheeta, C., \& Mohidin, A. R. (2010). Financial behavior amongst undergraduate students with and without financial education: A case among University Malaysia Sabah undergrades. Prosiding Perkem V, 1, 210-224.

Isabella, G., Pozzani, A. I., Chen, V. A., \& Gomes, M. B. P. (2012). Influence of discount price announcements on consumer's behavior. RAE Revista de Administracao de Empresas, 52(6), 657-671. https://doi.org/10.1590/S0034-75902012000600007

Jariah, M., Husniyah, A. R., Laily, P., \& Britt, S. (2004). Financial behavior and problems among university students: Need for financial education. Journal of Personal Finance, 3(1), 82-96.

Kahneman, D., \& Tversky, A. (1984). Choices, values, and frames. American Psychologist, 39(4), 341-350. https://doi.org/10.1037/0003-066X.39.4.341

Kazmi, S. H. A. (2015). Developments in promotion strategies: Review on psychological streams of consumers. International Journal of Marketing Studies, 7(3), 1-12. https://doi.org/10.5539/ijms.v7n3p129

Klein, W. M., \& Kunda, Z. (1992). Motivated person perception: Constructing justifications for desired beliefs. Journal of Experimental Social Psychology, 28(2), 145-168. https://doi.org/10.1016/0022-1031(92)90036-J

Krosch, A. R., Figner, B., \& Weber, E. U. (2012). Choice processes and their post-decisional consequences in morally conflicting decisions. Judgment and Decision Making, 7(3), 224-234.

Kunda, Z. (1990). The case for motivated reasoning. Psychological Bulletin, 108(3), 480-498. https://doi.org/10.1037/0033-2909.108.3.480

LaBarge, M. C., \& Stinson, J. L. (2014). The role of mental budgeting in philanthropic decision-making. Nonprofit and Voluntary Sector Quarterly, 43(6), 993-1013. https://doi.org/10.1177/0899764013489776

Lee, J. E., \& Chen-Yu, J. H. (2018). Effects of price discount on consumers' perceptions of savings, quality, and value for apparel products: Mediating effect of price discount affect. Fashion and Textiles, 5(1), 1-21. https://doi.org/10.1186/s40691-018-0128-2

Levav, J., \& Mcgraw, A. P. (2009). Emotional accounting: How feelings about money influence consumer choice. Journal of Marketing Research, 46(1), 66-80. https://doi.org/10.1509/jmkr.46.1.66

Loewenstein, G. (1996). Out of control: Visceral influences on behavior. Organizational Behavior and Human Decision Processes, 65(3), 272-292. https://doi.org/10.1006/obhd.1996.0028

Ly, K., Mazar, N., Zhao, M., \& Soman, D. (2013). A practitioner's guide to nudging. Rotman School of Management University of Toronto.

Malaviya, P., \& Sivakumar, K. (2002). The influence of choice justification and stimulus meaningfulness on the attraction effect. Journal of Marketing Theory and Practice, 10(4), 20-29. https://doi.org/10.1080/10696679.2002.11501923

Marin, G., Sabogal, F., Marin, B. V., Otero-Sabogal, R., \& Perez-Stable, E. J. (1987). Development of a short acculturation scale for hispanics. Hispanic Journal of Behavioral Sciences, 9(2), 183-205. https://doi.org/10.1177/07399863870092005

Maslow, A. H. (1943). A Theory of Human Motivation. Psychological Review, 50(4), 370-396. https://doi.org/10.1037/h0054346

Milkman, K. L., Bazerman, M. H., Beshears, J., \& Rogers, T. (2007). Mental accounting and small windfalls: Evidence from an online grocer mental. Havard Business School. 
Milkman, K. L., Rogers, T., \& Bazerman, M. H. (2008). Harnessing our inner angels and demons: What we have learned about want/should conflicts and how that knowledge can help us reduce shortsighted decision making. Perspectives on Psychological Science, 3(4), 324-338. https://doi.org/10.1111/j.1745-6924.2008.00083.x

Milkman, K. L., Rogers, T., \& Bazerman, M. H. (2010). I'll have the ice cream soon and the vegetables later: A study of online grocery purchases and order lead time. Marketing Letters, 21(1), 17-35. https://doi.org/10.1007/s11002-009-9087-0

Moon, C. S., Ohk, K., \& Choi, C. (2014). Gender differences in financial literacy among Chinese university students and the influential factors. Asian Women, 30(2), 3-25. https://doi.org/10.14431/aw.2014.03.30.2.3

Mowen, J. C., \& Voss, K. E. (2008). On building better construct measures: Implications of a general hierarchical model. Psychology and Marketing, 25(6), 485-505. https://doi.org/10.1002/mar.20221

Nidar, S. R., \& Bestari, S. (2012). Personal financial literacy among university students (Case study at Padjadjaran University students, Bandung, Indonesia). World Journal of Social Sciences, 2(4), 162-171.

Nordgren, L. F., van der Pligt, J., \& van Harreveld, F. (2008). The instability of health cognitions: Visceral states influence self-efficacy and related health beliefs. Health Psychology, 27(6), 722-727. https://doi.org/10.1037/0278-6133.27.6.722

Okada, E. M. (2005). Justification effects on consumer choice of hedonic and utilitarian goods. Journal of Marketing Research, 42(1), 43-53. https://doi.org/10.1509/jmkr.42.1.43.56889

Pappang, R., \& Anastasia, N. (2019). The impact of perceived financial literacy and parental norm towards money management of Bidikmisi student. Petra International Journal of Business Studies, 2(2), 71-77. https://doi.org/10.9744/ijbs.2.2.71-77

Polman, E., Ruttan, R. L., \& Peck, J. (2016). Using curiosity to increase the choice of "should" options. https://www.apa.org/news/press/releases/2016/08/using-curiosity.pdf

Polman, E., Ruttan, R., \& Peck, J. (2017). Curiosity and want/should conflicts. Advances in Consumer Research, 45, 818-821.

Prelec, D., \& Loewenstein, G. (1998). The red and the black: Mental accounting of savings and debt. Marketing Science, 17(1), 4-28.

Pyszczynski, T., \& Greenberg, J. (1987). Toward an integration of cognitive and motivational perspectives on social inference: A biased hypothesis-testing model. Advances in Experimental Social Psychology, 20, 297-340. https://doi.org/10.1016/S0065-2601(08)60417-7

Read, D., Loewenstein, G., \& Kalyanaraman, S. (1999). Mixing virtue and vice: Combining the immediacy effect and the diversification heuristic. Journal of Behavioral Decision Making, 12(4), 257-273. https://doi.org/10.1002/(SICI)1099-0771(199912)12:4<257::AID-BDM327>3.0.CO;2-6

Saidi, N. A., Khairuddin, N. A., Samat, N. A. A., Rahman, N. A. A., \& Jalil, N. F. A. (2016). Determinants of financial problems among adults. International Journal of Accounting, Finance and Business, $1(1), 18-23$.

Sanitioso, R., Kunda, Z., \& Fong, G. T. (1990). Motivated recruitment of autobiographical memories. Journal of Personality and Social Psychology, 59(2), 229-241. https://doi.org/10.1037/00223514.59.2.229 
Scheer, L. K., Shehryar, O., \& Wood, C. M. (2010). How budget constraints impact consumers' response to discount presentation formats. Journal of Product and Brand Management, 19(3), 225-232. https://doi.org/10.1108/10610421011046201

Schweitzer, M. E., \& Hsee, C. K. (2002). Stretching the truth: Elastic justification and motivated communication of uncertain information. Journal of Risk and Uncertainty, 25(2), 185-201. https://doi.org/10.1023/A:1020647814263

Scott, C. A., \& Yalch, R. F. (1978). A test of the self-perception explanation of the effects of rewards on intrinsic interest. Journal of Experimental Social Psychology, 14(2), 180-192. https://doi.org/10.1016/0022-1031(78)90024-0

Shefrin, H. M., \& Thaler, R. H. (1988). The behavioral life-cycle hypothesis. Economic Inquiry, 26(4), 609643. https://doi.org/10.1111/j.1465-7295.1988.tb01520.x

Soman, D., \& Cheema, A. (2011). Earmarking and partitioning: Increasing saving by low-income households. Journal of Marketing Research, 48(SPL), S14-S22. https://doi.org/10.1509/jmkr.48.SPL.S14

Susilowati, N., Latifah, L., \& Jariyah. (2017). College student financial behavior: An empirical study on the mediating effect of attitude toward money. Advanced Science Letters, 23(8), 7468-7472. https://doi.org/10.1166/asl.2017.9500

Sussman, A. B., \& O'Brien, R. L. (2016). Knowing when to spend: Unintended financial consequences of earmarking to encourage savings. Journal of Marketing Research, 53(5), 790-803. https://doi.org/10.1509/jmr.14.0455

Taormina, \& Gao. (2013). Maslow and the motivation hierarchy: Measuring satisfaction of the needs. The American Journal of Psychology, 126(2), 155-177. https://doi.org/10.5406/amerjpsyc.126.2.0155

Tetlock, P. E., \& Boettger, R. (1989). Accountability: A social magnifier of the dilution effect. Journal of Personality and Social Psychology, 57(3), 388-398. https://doi.org/10.1037/00223514.57.3.388

Tetlock, P. E., \& Kim, J. I. (1987). Accountability and judgment processes in a personality prediction task. Journal of Personality and Social Psychology, 52(4), 700-709. https://doi.org/10.1037/00223514.52.4.700

Tetlock, P. E., Skitka, L., \& Boettger, R. (1989). Social and cognitive strategies for coping with accountability: Conformity, complexity, and bolstering. Journal of Personality and Social Psychology, 57(4), 632-640. https://doi.org/10.1037/0022-3514.57.4.632

Thaler, R. H. (2008). Mental accounting and consumer choice. Marketing Science, 27(1), 15-25. https://doi.org/10.1287/mksc.1070.0330

Thaler, R. H., \& Benartzi, S. (2004). Save more tomorrow: Using behavioral economics to increase employee saving. Journal of Political Economy, 112(S1), S164-S187. https://doi.org/10.1086/380085

Thaler, R. H., \& Shefrin, H. M. (1981). An economic theory of self-control. Journal of Political Economy, 89(2), 392-406. https://doi.org/10.1086/260971

Tversky, A., \& Kahneman, D. (1981). The framing of decisions and the psychology of choice. Science, 211(4481), 453-458. https://doi.org/10.1126/science.7455683

Weber, E. U., \& Lindemann, P. G. (2008). From intuition to analysis: Making decision with your head, your heart, or by the book. In Intuition in judgment and decision making (pp. 191-208). 
Wertenbroch, K. (1998). Consumption self-control by rationing purchase quantities of virtue and vice. Marketing Science, 17(4), 317-337. https://doi.org/10.1287/mksc.17.4.317

Yao, R., \& Meng, X. (2018). Credit card usage among college students in China. Journal of Financial Counseling and Planning, 29(2), 304-315. https://doi.org/10.1891/1052-3073.29.2.304

Zhou, H., \& Gu, Z. (2015). The effect of different price presentations on consumer impulse buying behavior: The role of anticipated regret. American Journal of Industrial and Business Management, 05(01), 27-36. https://doi.org/10.4236/ajibm.2015.51004 